Article

\title{
No Limits of Acceptable Change: A Proposed Research Framework for Informing Visitor Use Management in the Context of Cultural Resources
}

\author{
Zachary D. Miller 1,2,3,*(D), Wayne Freimund ${ }^{2,3,4}$, Stefani A. Crabtree ${ }^{1,5,6,7}$ and Ethan P. Ryan ${ }^{8,9}$ \\ 1 Department of Environment and Society, Utah State University, Logan, UT 84322, USA; \\ Stefani.crabtree@usu.edu \\ 2 Institute of Outdoor Recreation and Tourism, Utah State University, Logan, UT 84322, USA; \\ Wayne.freimund@usu.edu \\ 3 Ecology Center, Utah State University, Logan, UT 84322, USA \\ 4 Department of Environment and Society, Utah State University, Moab, UT 84532, USA \\ 5 The Santa Fe Institute, Santa Fe, NM 87501, USA \\ 6 ARC Centre of Excellence for Australian Biodiversity and Heritage, James Cook University, \\ Cairns, QLD 4870, Australia \\ 7 Crow Canyon Research Institute, Cortez, CO 81321, USA \\ 8 Department of Anthropology, University of Montana, Missoula, MT 59812, USA; ethan@cannonheritage.com \\ 9 Cannon Heritage Consultants, Inc., Logan, UT 84321, USA \\ * Correspondence: Zachary.miller@usu.edu
}

check for

updates

Citation: Miller, Z.D.; Freimund, W.; Crabtree, S.A.; Ryan, E.P. No Limits of Acceptable Change: A Proposed Research Framework for Informing Visitor Use Management in the Context of Cultural Resources. Sustainability 2021, 13, 377. https:// doi.org/10.3390/su13010377

Received: 1 December 2020

Accepted: 1 January 2021

Published: 4 January 2021

Publisher's Note: MDPI stays neutral with regard to jurisdictional clai$\mathrm{ms}$ in published maps and institutional affiliations.

Copyright: (C) 2021 by the authors. Licensee MDPI, Basel, Switzerland. This article is an open access article distributed under the terms and conditions of the Creative Commons Attribution (CC BY) license (https:// creativecommons.org/licenses/by/ $4.0 /)$.

\begin{abstract}
Cultural resources are commonly defined as resources that provide material evidence of past human activities. These resources are unique, as they are both finite and non-renewable. This provides a challenge for traditional visitor use management since these resources have no limits of acceptable change. However, with nearly every national park in the US containing cultural resources, coupled with ever-growing visitation, it is essential that managers of parks and protected areas have the ability to make science-informed decisions about cultural resources in the context of visitor use management. We propose a framework that can help provide context and exploration for these challenges. Drawing on previous literature, this framework includes risk-based approaches to decision making about visitor use; visitor cognitions related to cultural resources; emotions, mood, and affect related to cultural resource experiences; creating and evaluating interpretive programs; deviant visitor behaviors related to cultural resources; and co-management.
\end{abstract}

Keywords: cultural resource management; national parks; visitor use management; anthropology; archeology

\section{Introduction}

As early as 1936 [1], people wondered how we can manage access to resources in parks and protected areas without degrading their essential qualities. This idea of balancing the protection of resources and opportunities for visitors to experience those same resources has been a central part of parks and protected areas since their inception. The earliest scientific articulation of this came from Wagar [2], who applied the concept of carrying capacity to recreation. However, Wagar quickly discovered that a "resource-oriented view must be augmented by consideration of human values." Decades later, the field that rose from this insight is called visitor use management (VUM [3]).

In VUM, Limits of Acceptable Change (LAC [4]) was an early framework that incorporated the human value considerations Wagar [2] emphasized. Since LAC, several other frameworks were created for the management of and planning for visitor use in parks and protected areas that further incorporate social considerations of resource impacts. These frameworks include Visitor Use and Experience Preference (VERP [5]), Visitor Impact Management (VIM [6]), and the more recent Interagency Visitor Use Management Framework 
(IVUMF [7]). Internationally, the Tourism Optimization Management Model (TOMM) was developed in Australia for similar visitor use management purposes [8].

All of the VUM frameworks mentioned above are different expressions of a generalized Management-By-Objectives (MBO) process (see Figure 1; Ref. [3]). This generalized MBO process has five steps that include (1) establishing management objectives, (2) identifying indicators and thresholds, (3) monitoring, (4) implementing management actions, and (5) repeating numbers 3 to 5 . Regardless of what articulation of $\mathrm{MBO}$ processes is used (e.g., LAC, VERP, VIM, etc.), thresholds are a central concept in VUM (Step 2 in the MBO). Thresholds evaluate how much change in resource conditions is acceptable to visitors, and explicitly incorporate social values, usually through the use of social norm theory [9-11]. The thresholds concept is critical to VUM because any level or type of visitor use will lead to at least some resource impact [12], and even the name LAC infers some change in conditions is acceptable. Therefore, VUM frameworks focus on how much resource impact should be allowed in the context of the management objectives (Step 1 in the MBO), and how to manage this impact (Step 3 in the MBO).

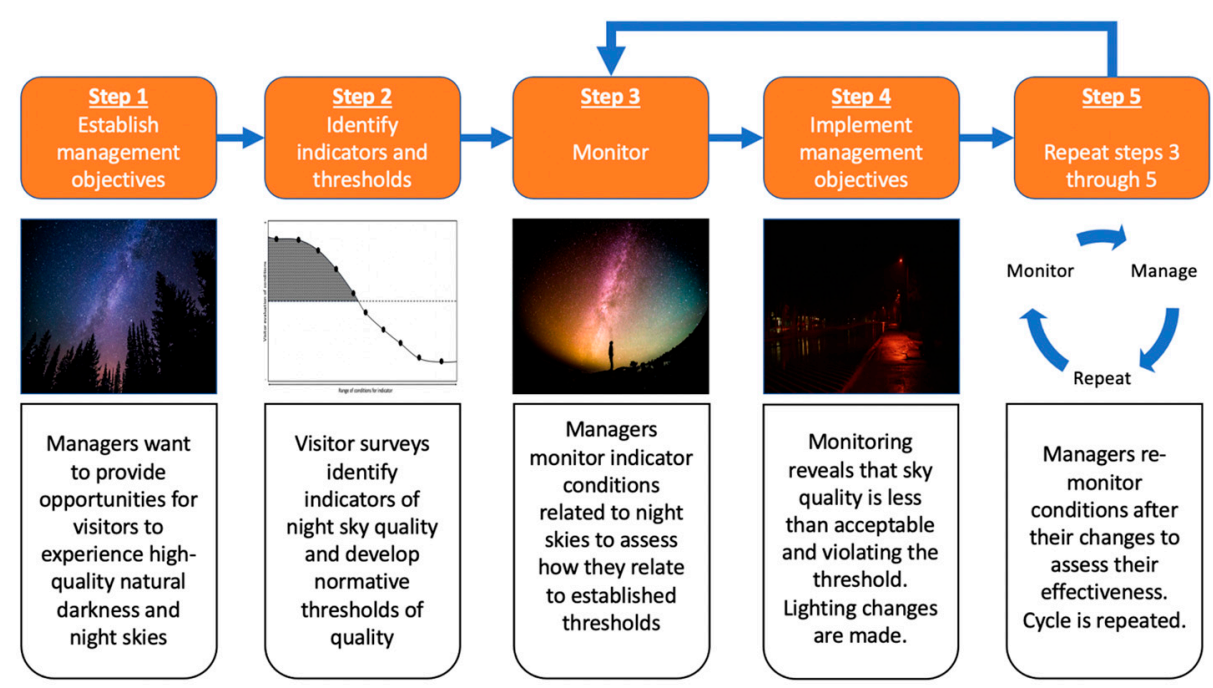

Figure 1. A hypothetical example of the management-by-objectives process for the renewable resource of natural darkness. Photos courtesy of Zach Miller and Pixbay.

VUM frameworks were successful in informing the management of many different resource issues. This includes issues related to natural soundscapes [10,13], vegetation damage [14], and crowding in a variety of environments and activities [5,15-17]. The success of the thresholds approach to VUM is predicated on the fact that the resource issues addressed are inherently renewable; natural quiet can be restored, vegetation will grow back, and solitude can re-emerge. However, for some resources, renewal is not possible.

\section{Visitor Use Management in the Context of Non-Renewable Cultural Resources}

Numerous parks and protected areas were specifically established for their unique cultural resources, which are defined as resources that contain material evidence of past human activities [18]. This includes areas like Mesa Verde National Park (Mesa Verde, CO, USA), Chaco Culture National Historic Park (New Mexico, NW, USA), and Effigy Mounds National Monument (Harpers Ferry, IA, USA). Additionally, many other park units contain cultural resources, such as Grand Canyon National Park (Fredonia, AZ, USA) and Canyonlands National Park (Moab, UT, USA). In fact, almost every national park unit in the USA contains cultural resources [18], and as of 2020 over 82,000 archaeological sites exist within the U.S. National Park System (M. Roller, personal communication, 20 July 2020).

Generally, parks and protected areas are legally mandated to protect resources while also providing for their public enjoyment [19]. This includes cultural resources. Mandates aside, tourism to these destinations generates a variety of benefits. This includes economic 
contributions to rural communities [20-22], reduced poverty [23], financial donations to related philanthropic organizations [24], and increased support for conservation [25]. These benefits are essential to a sustainable future for parks and protected areas [3].

Debates about appropriate management of cultural resources emerged in the late 1800s in the United States. For instance, a large area of the American Southwest was proposed as a national park in 1888 to specifically protect cultural resources [26]. Since then, the debate has continued. The fundamental challenge with cultural resources is that they are finite and non-renewable [18]. Because of these qualities (e.g., finite and nonrenewable), cultural resources have no limits of acceptable change. Thus, no thresholds can be established for cultural resources. Earlier approaches to managing cultural resources using traditional VUM concepts neglected to recognize this [27,28]. Even if visitors were accepting of impacts to cultural resources, (i.e., some level of graffiti on rock art), the finite and non-renewable qualities of cultural resources would render them impaired. Managers (and visitors) may be willing to allow some overflights to occur, some vegetation to be trampled, or some crowding to occur. But for cultural resources, similar degradation is not acceptable as it leads to permanent loss of the resource. Therefore, we need new strategies and approaches for informing the management of cultural resources in the context of visitor use management.

\section{A Proposed Research Framework for Informing Visitor Use Management in the Context of Cultural Resources}

Although thresholds are a central part of many VUM approaches, other theories and concepts can be used to provide a basis for informing VUM in the context of cultural resource management. Drawing on these past works, we propose the following research framework (Figure 2). Critically, we draw on six concepts and describe how they integrate as a science-based approach for managing visitor use and experiences related to cultural resource management.

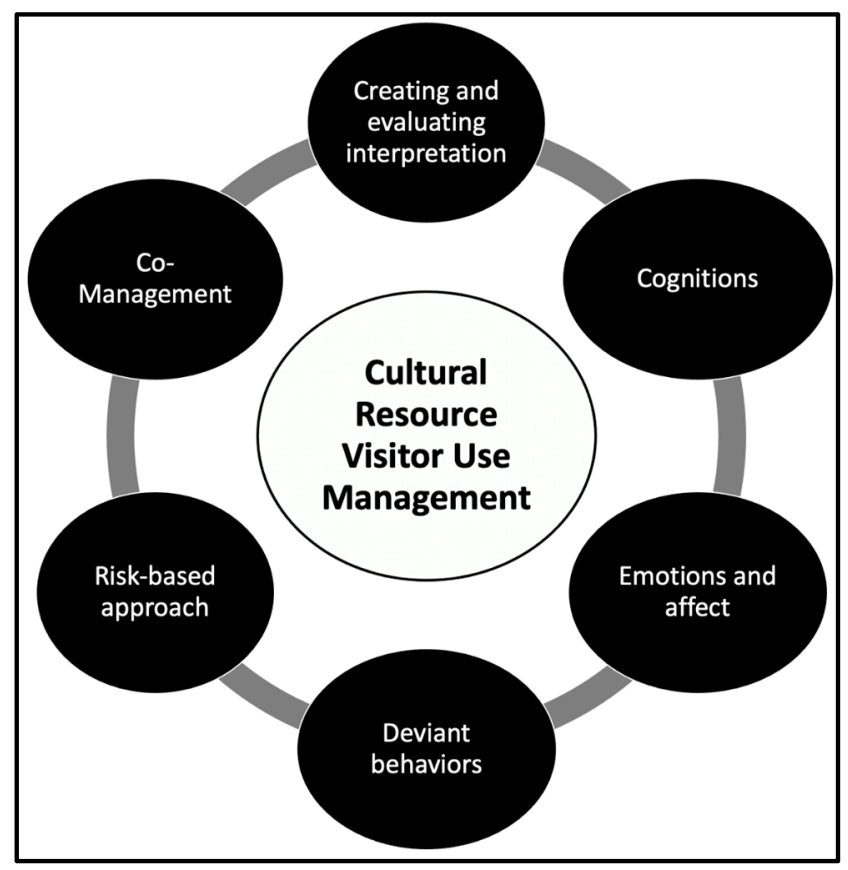

Figure 2. A framework for visitor use management in the context of cultural resources.

\subsection{A Risk-Based Approach to Decision-Making about Visitor Use}

One proposed solution for better managing cultural resources in the context of visitor use is moving to a risk-based approach to decision making. This is similar to other scarce and highly sensitive resources, like endangered species [29]. This risk-based approach could be developed through identifying the drivers of risk to cultural resources from visitor 
use. Drivers of risk may include type of access (motorized/non-motorized), amount of use (i.e., density of visitors), distance from access point, public information availability, and various other drivers of risk. A variety of methods could be used to identify these drivers of risk, including Delphi methods, spatial modeling, and visitor surveys and interviews. Like other risk-based approaches [29], a risk matrix could be constructed that allows managers to evaluate the risk posed to cultural resources from visitor use and make better-informed, scientifically grounded decisions. Critically, these risks need to be clearly defined and will be specific to unique resource, as some resources may be more prone to theft while others may be more prone to additions from visitors. For instance, buffalo jump sites where indigenous people drove American Bison off cliffs contain small fragments of bone, which can easily be picked up and removed by visitors. In contrast, some non-indigenous Americans will leave crystals and related items in places like Chaco Culture National Historic Site, which is considered offensive to some indigenous people. The type and severity of risks can be associated with potential management actions, as is done in other visitor use management contexts [30].

\subsection{Visitor Cognitions Related to the Management of Cultural Resources}

Cognitions include many well-explored psychological concepts, like values, attitudes, beliefs, subjective norms, and perceived control [31-33]. Support for a variety of management actions related to resource management is also considered a cognition [34,35]. Many of the concepts work together to form a cognitive hierarchy, which identifies different human-resource relationships, predict participating in recreation activities, and explain human behavior $[33,36,37])$. For instance, understanding visitor attitudes towards the Archaeological Resources Protection Act (ARPA) of 1979 and even the Antiquities Act of 1906 may predict support for management actions being considered for an area. Further comparisons among types of visitors can also be made, such as comparisons among local and non-local visitors.

\subsection{Emotions, Mood, and Affect Related to Cultural Resource Experiences}

Although cognition-related studies in VUM are much more common, recent studies highlight the need to better understand how emotions and affect are related to the visitor experience. Past work shows that light pollution influences different affective states during experiences with night skies [38], and that vegetation impacts from recreation users negatively impacts affective states in outdoor experiences [39]. Furthermore, outdoor experiences reduce stress [40,41]. Further development of these concepts needs to be explored in the context of visitor use related to cultural resources. One emerging area that may show promise is in exploring the concept of awe [42]. Awe is generally defined by a perception of vastness and a need for accommodation [43], but recent works show other elements like physical sensations, perception of time, self-diminishment, and connectedness are also important [42]. Awe is often elicited by vast landscapes and natural scenery [42,44], and certain types of cultural resources may elicit similar feelings of awe from visitors during and immediately after their experience.

\subsection{Creating and Evaluating Interpretive Programs}

Interpretation is the act of communicating with others to enhance the experience of resources, influence attitudes about resources, or change behaviors related to resources [24]. All three of these purposes are relevant to cultural resource management. As noted by Mazzola [27], interpretation needs to adjust to a modern audience. Some parks and protected areas are already creating new interpretive programming that incorporates some adjustments. For instance, at Mesa Verde National Park the Visitor and Research Center introduces visitors to descendant communities of the Ancestral Pueblo. Drawing on previous work, research can be adapted to understand how to create frameworks for effective communication [45,46], as well as for evaluating the impacts of interpretation $[47,48]$. 


\subsection{Deviant Visitor Behaviors Related to Cultural Resources}

Although interpretation may influence some forms of behavior, it is generally not effective for behaviors that are deliberately illegal [49]. For cultural resources, this includes theft, purchase, sale, and vandalism. Although law enforcement is one option, it can be very difficult to provide consistent law enforcement across large and remote landscapes, and law enforcement resources are often focused on systemic looting events [50].

Most recreation research focuses on the more positive, benefit-based aspects of participation [51,52]. However, some recreation experiences can break the law, engage in social taboos, and/or perform other deviant behaviors. These types of experiences are generally referred to as "purple leisure" [53,54], and they are severely understudied [55]. Limited past research on purple leisure focused on internet use and pornography [56], alcohol and illegal drug use among college students [55], and the transition from adolescence to adulthood [57]. The findings from these studies may be particularly relevant to cultural resource management since graffiti, collecting of potsherds or other artifacts, and other forms of damage are perennial issues. Recently, concerns about the role of social media in highlighting and further fostering deviant behaviors that impact resources make this a particularly salient issue $[58,59]$.

\subsection{Co-Management of Visitor Access to Cultural Resources with Indigenous Groups}

All pre-colonial cultural resources in parks and protected areas have significant value to indigenous groups. In these cases, it is essential that relevant indigenous groups are part of the research and management process of parks and protected areas [60]. This includes issues related to visitor use. One potentially effective approach to this is comanagement [60,61]. Although some agencies may involve indigenous groups in planning, stewardship, and tribal access, co-management goes beyond involvement and shares powers and responsibilities between the government and local indigenous groups [61]. Most examples of co-management with indigenous groups in the US come from wildlife and fisheries, with scant use of the framework in terrestrial protected areas [61,62]. Investment in co-management with indigenous groups is likely to increase successful cultural resources in the context of visitor use for multiple reasons. These reasons include a deeper understanding of the land, artifacts, and places to enhance interpretation, dispelling myths about native people among visitors, and incorporate Traditional Ecological Knowledge.

\section{Conclusions}

The finite and non-renewable characteristics of cultural resources make them a unique challenge in the context of visitor use. Because these cultural resources have no limit of acceptable change, visitor use management has largely lacked the ability to create scienceinformed decision making for parks and protected areas. Given their presence in nearly every national park across the US and coupled with ever-growing visitation, it is essential that managers have the ability to make sound decisions about managing visitor use in the context of cultural resource management. The framework provided in this manuscript provides a useful path forward for addressing these challenges.

Although the framework presents the different areas of exploration (e.g., deviant behaviors, cognitions, etc.) as discrete, it is important to realize that there is much overlap and synergy that can be gained across them. For instance, co-management approaches may lead to an indigenous-lead interpretive program that increases emotional and cognitive experiences for visitors. Likewise, a study into deviant behaviors related to cultural resources may reveal risk factors for cultural resources previously unidentified. Continual exploration and re-evaluation of this framework will surely lead to better stewardship of cultural resources into the future.

While we suggest this framework will lead to a clearer ability to manage cultural resources in the context of visitor use, this is not a step-by-step process. Managers do not have to begin with a risk-based approach, but can begin assessing emotion and affect or deviant behaviors. Rather, we suggest that the six components of this framework are 
critical for preserving cultural resources while creating providing visitor experiences where possible. While there may be other aspects to consider, we suggest that the finite nature of cultural resources lends them to needing a different framework than renewable resources, as these cultural resources have no limits of acceptable change.

Author Contributions: Z.D.M. conceptualized and wrote the first draft. W.F., S.A.C., and E.P.R. expanded the writing and concepts in future drafts. All authors contributed equally to finalizing and editing the manuscript. All authors have read and agreed to the published version of the manuscript.

Funding: This research received no external funding.

Conflicts of Interest: The authors declare no conflict of interest.

\section{References}

1. Sumner, E.L. Special Report on a Wildife Study in the High Sierra in Sequoia and Yosemite National Parks and Adjacent Territory; US National Park Service Records, National Archives: Washington, DC, USA, 1936.

2. Wagar, J.A. The Carrying Capacity of Wild Lands for Recreation; Society of American Foresters: Washington, DC, USA, 1964.

3. Miller, Z.D.; Rice, W.L.; Taff, B.D.; Newman, P. Concepts for understanding the visitor experience in sustainable tourism. In $A$ Research Agenda for Sustainable Tourism; McCool, S., Bosak, K., Eds.; Edward Elgar Publishing: Cheltenham, UK, 2019; pp. 53-69.

4. Stankey, G.H.; McCool, S.F.; Stokes, G.L. Limits of acceptable change: A new framework for managing the Bob Marshall Wilderness Complex. West. Wildlands 1984, 10, 33-37.

5. Manning, R.E.; Lime, D.W.; Hof, M.; Freimund, W.A. The visitor experience and resource protection (VERP) process: The application of carrying capacity to Arches National Park. In The George Wright Forum; George Wright Society: Hancock, MI, USA, 1995; Volume 12, pp. 41-55.

6. Graefe, A.R.; Kuss, F.R.; Vaske, J.J. Visitor Impact Management: The Planning Framework; National Parks and Conservation Association: Washington, DC, USA, 1990; Volume II.

7. Interagency Visitor Use Management Framework (IVUMF). The Interagency Visitor Use Management Council. Available online: http:/ / visitorusemanagement.nps.gov (accessed on 2 January 2021).

8. Manidis Roberts Consultants. Developing a Tourism Optimization Management Model (TOMM), a Model to Monitor and Manage Tourism on Kangaroo Island, South Australia. 1997. Available online: http:/ /www.utok.cz/sites/default/files/data/ USERS/u28/TOMM\%20Tourism\%20optimisation\%20management\%20model.pdf (accessed on 12 September 2020).

9. Manning, R.E.; Freimund, W.A.; Lime, D.W.; Pitt, D.G. Crowding norms at frontcountry sites: A visual approach to setting standards of quality. Leis. Sci. 1996, 18, 39-59. [CrossRef]

10. Pilcher, E.J.; Newman, P.; Manning, R.E. Understanding and managing experiential aspects of soundscapes at Muir Woods National Monument. Environ. Manag. 2009, 43, 425-435. [CrossRef]

11. Vaske, J.J.; Shelby, B.; Graefe, A.R.; Heberlein, T.A. Backcountry encounter norms: Theory, method, and empirical evidence. J. Leis. Res. 1986, 18, 113-138. [CrossRef]

12. Manning, R.E. Studies in Outdoor Recreation: Search and Research for Satisfaction; Oregon State University Press: Corvallis, OR, USA, 2011.

13. Miller, Z.D.; Ferguson, L.A.; Newman, P.; Ferguson, M.; Tipton, N.; Sparrow, V.; Taff, B.D. Developing visitor thresholds of sound from shale natural gas compressors for motorized and non-motorized recreation users in Pennsylvania State Forests. Appl. Acoust. 2020, 157, 107012. [CrossRef]

14. D'Antonio, A.; Monz, C.; Newman, P.; Lawson, S.; Taff, D. Enhancing the utility of visitor impact assessment in parks and protected areas: A combined social-ecological approach. J. Environ. Manag. 2013, 124, 72-81. [CrossRef]

15. Inglis, G.J.; Johnson, V.I.; Ponte, F. Crowding norms in marine settings: A case study of snorkeling on the Great Barrier Reef. Environ. Manag. 1999, 24, 369-381. [CrossRef] [PubMed]

16. Whittaker, D. Capacity norms on bear viewing platforms. Hum. Dimens. Wildl. 1997, 2, 37-49. [CrossRef]

17. Williams, D.R.; Roggenbuck, J.W.; Bange, S. The Effect of Norm-Encounter Compatability on Crowding Perceptions, Experience and Behavior in River Recreation Settings. J. Leis. Res. 1991, 23, 154-172. [CrossRef]

18. NPS. Cultural Resource Management Guideline. 2020. Available online: https://www.nps.gov/parkhistory/online_books/nps2 8/28intro.htm (accessed on 5 October 2020).

19. Organic Act of 1916. 16 U.S.C. §§ 1-4. Available online: https://www.nps.gov/foun/learn/management/upload/1916\%2 0ACT\%20TO\%20ESTABLISH\%20A\%20NATIONAL\%20PARK\%20SERVICE-5.pdf (accessed on 2 January 2021).

20. Ardoin, N.; Wheaton, M.; Bowers, A.W.; Hunt, C.A.; Durham, W.H. Nature-based tourism's impact on environmental knowledge, attitudes, and behavior: A review and analysis of the literature and potential future research. J. Sustain. Tour. 2015, 23, 838-858. [CrossRef]

21. Moore, S.A.; Rodger, K.; Taplin, R. Moving beyond visitor satisfaction to loyalty in nature- based tourism: A review and research agenda. Curr. Issues Tour. 2015, 18, 667-683. [CrossRef]

22. Pinkus, E.; Moore, S.A.; Taplin, R.; Pearce, J. Re-thinking visitor loyalty at 'once in a life- time' nature-based tourism destinations: Empirical evidence from Purnululu National Park, Australia. J. Outdoor Recreat. Tour. 2016, 16, 7-15. [CrossRef] 
23. Snyman, S. The role of private sector ecotourism in local socio-economic development in southern Africa. J. Ecotour. 2017, 16, 247-268. [CrossRef]

24. Ham, S. Interpretation: Making a Difference on Purpose; Fulcrum Publishing: Golden, CO, USA, 2013.

25. Jorgenson, J.; Nickerson, N.; Dalenberg, D.; Angle, J.; Metcalf, E.; Freimund, W. Measuring visitor experiences: Creating and testing the tourism autobiographical memory scale. J. Travel Res. 2019, 58, 566-578. [CrossRef]

26. Rogers, E. History of Legislation Relating to the National Park System through the 82d Congress; United States Department of Interior: Washington, DC, USA, 1958.

27. Mazzola, B. Archaeological Tourism Opportunity Spectrum: Experience Based Management and Design as Applied to Archaeological Tourism; All Graduate Plan B and Other Reports; Utah State University: Logan, UT, USA, 2015. Available online: https: / / digitalcommons.usu.edu/cgi/viewcontent.cgi?article=1539\&context=gradreports (accessed on 28 August 2020).

28. Valliere, W.; Manning, B. Applying the Visitor Experience and Resource Protection Framework (VERP) to Cultural Resources in National Parks. In Proceedings of the 2002 Northeastern Recreation Research Symposium, Newtown Square, PA, USA, 13-16 April 2002.

29. USFWS. (n.d.). California Condor Wind Energy Working Group. Available online: https://www.fws.gov/ventura/docs/species/ windenergy/ThreatMatrix_terms\%20and\%20use_final.pdf (accessed on 28 August 2020).

30. Manning, R.E.; Anderson, L.E.; Pettengill, P. Managing Outdoor Recreation: Case Studies in the National Parks; CABI: Boston, MA, USA, 2017.

31. Fishbein, M.; Ajzen, I. Predicting and Changing Behavior: The Reasoned Action Approach; Taylor \& Francis: Abingdon, UK, 2011.

32. Manfredo, M.J. Who Cares about Wildlife? Social Science Concepts for Exploring Human-Wildlife Relationships and Conservation Issues; Spring Science+Business Media, LLC: New York, NY, USA, 2008.

33. Teel, T.L.; Dietsch, A.M.; Manfredo, M.J. A (Social) psychology approach in conservation. In The Conservation Social Sciences: What? How? and Why; Bennett, N.J., Roth, R., Eds.; Canadian Wildlife Federation and Institute for Resources, Environment, and Sustainability: Vancouver, BC, Canada, 2015; pp. 21-25.

34. Hermann, N.; Voß, C.; Menzel, S. Wildlife value orientations as predicting factors in support of reintroducing bison and of wolves migrating to Germany. J. Nat. Conserv. 2013, 21, 125-132. [CrossRef]

35. Jacobs, M.; Vaske, J.; Sijtsma, M. Predictive potential of wildlife value orientations for acceptability of management interventions. J. Nat. Conserv. 2014, 22, 377-383. [CrossRef]

36. Fulton, D.C.; Manfredo, M.J.; Lipscomb, J. Wildlife value orientations: A conceptual and measurement approach. Hum. Dimens. Wildl. 1996, 1, 24-47. [CrossRef]

37. Miller, Z.D. The enduring use of the Theory of Planned Behavior. Hum. Dimens. Wildl. 2017, 22, 583-590. [CrossRef]

38. Benfield, J.A.; Nutt, R.J.; Taff, B.D.; Miller, Z.D.; Costigan, H.; Newman, P. A laboratory study of the psychological impact of light pollution in national parks. J. Environ. Psychol. 2018, 57, 67-72. [CrossRef]

39. Taff, B.D.; Benfield, J.; Miller, Z.D.; D'antonio, A.; Schwartz, F. The role of tourism impacts on cultural ecosystem services. Environments 2019, 6, 43. [CrossRef]

40. Ulrich, R.S. Effects of gardens on health outcomes: Theory and research. In Healing Gardens: Therapeutic Benefits and Design Recommendations; Marcus, C.C., Barnes, M., Eds.; John Wiley \& Sons, Inc.: New York, NY, USA, 1999; pp. $27-86$.

41. Ferraro, D.M.; Miller, Z.D.; Ferguson, L.A.; Taff, B.D.; Barber, J.; Newman, P.; Francis, C.D. The phantom chorus: Birdsong boosts human well-being in protected areas. Proc. R. Soc. B 2020, 287, 20201811. [CrossRef] [PubMed]

42. Yaden, D.B.; Kaufman, S.B.; Hyde, E.; Chirico, A.; Gaggioli, A.; Zhang, J.W.; Keltner, D. The development of the Awe Experience Scale (AWE-S): A multifactorial measure for a complex emotion. J. Posit. Psychol. 2019, 14, 474-488. [CrossRef]

43. Keltner, D.; Haidt, J. Approaching awe, a moral, spiritual, and aesthetic emotion. Cogn. Emot. 2003, 17, 297-314. [CrossRef] [PubMed]

44. Powell, R.B.; Brownlee, M.T.J.; Kellert, S.R.; Ham, S.H. From awe to satisfaction: Immediate affective responses to the Antarctic tourism experience. Polar Rec. 2011, 48, 145-156. [CrossRef]

45. Miller, Z.D.; Freimund, W.; Metcalf, E.C.; Nickerson, N.P.; Powell, R.B. Merging elaboration and the theory of planned behavior to understand bear spray behavior of day hikers in Yellowstone National Park. Environ. Manag. 2019, 63, 366-378. [CrossRef] [PubMed]

46. Vezeau, S.L.; Powell, R.B.; Stern, M.J.; Moore, D.D.; Wright, B.A. Development and validation of two scales to measure elaboration and behaviors associated with stewardship in children. Environ. Educ. Res. 2015, 23, 1-22. [CrossRef]

47. Brown, T.J.; Ham, S.H.; Hughes, M. Picking up litter: An application of theory-based communication to influence tourist behaviour in protected areas. J. Sustain. Tour. 2010, 18, 879-900. [CrossRef]

48. Taff, B.D.; Costigan, H.; Newman, P.; Mowen, A.; Smyth, J.M.; Newman, S.B. Civil War buff, to just buff: Examining communication strategies to influence physical activity behaviors in Gettysburg National Military Park. Recreat. Parks Tour. Public Health 2017, 1, 81-102. [CrossRef]

49. Manning, R.E. Emerging Principles for Using Information / Education in Wilderness Management. Int. J. Wilderness 2003, 9, 20-27.

50. Mozingo, J. A Sting in the Desert. Los Angeles Times. 2014. Available online: https://graphics.latimes.com/utah-sting/ (accessed on 28 August 2020).

51. Driver, B.L. Benefits-driven management of natural areas. Nat. Areas J. 1996, 16, 94-99. 
52. Rice, W.L.; Taff, B.D.; Miller, Z.D.; Newman, P.; Zipp, K.Y.; Pan, B.; Newton, J.N.; Antonio, A.D. Connecting motivations to outcomes: A study of park visitors' outcome attainment. J. Outdoor Recreat. Tour. 2020, 29, 100272. [CrossRef]

53. Curtis, J.E. Purple recreation. SPRE Annu. Educ. 1988, 3, 73-77.

54. Rojek, C. Deviant leisure: The dark side of free-time activity. In Leisure Studies: Prospects for the Twenty-First Century; Jackson, E.L., Burton, T.L., Eds.; Venture Publishing: State College, PA, USA, 1999; pp. 81-94.

55. Shinew, K.J.; Parry, D.C. Examining college students' participation in the leisure pursuits of drinking and illegal drug use. J. Leis. Res. 2005, 37, 364-386. [CrossRef]

56. Jackson, E.L. Leisure and the Internet. J. Phys. Educ. Recreat. Dance 1999, 70, 18-22. [CrossRef]

57. Raymore, L.A.; Barber, B.L.; Eccles, J.S.; Godbey, G.C. Leisure behavior pattern stability during the transition from adolescence to young adulthood. J. Youth Adolesc. 1999, 28, 79-103. [CrossRef]

58. Miller, Z.D.; Taff, B.D.; Newman, P.; Lawhon, B. A proposed research agenda on social media's role in visitor use and experience in parks and protected areas. J. Park Recreat. Adm. 2019, 37, 134-142. [CrossRef]

59. Modern Hiker. Why the Creepytings National Parks Vandalism Is a Big Deal. 2020. Available online: https://modernhiker.com/ why-the-creepytings-national-parks-vandalism-is-a-big-deal/ (accessed on 28 August 2020).

60. Leaman, G. Co-managing parks with aboriginal communities: Improving outcomes for conservation and cultural heritage. George Wright Forum. 2013, 30, 287-294.

61. Dugelby, B. Collaborative Management of Protected Areas with Examples of Collaboration between Native American Tribes and US Federal and State Agencies; Round River Conservation Studies: Salt Lake City, UT, USA, 2012. Available online: https://www.roundriver. org/wp-content/uploads/2019/10/Collaborative-Management-of-Protected-Areas.pdf (accessed on 5 October 2020).

62. Nie, M. The use of co-management and protected land-use designations to protect tribal cultural resources and reserved treaty rights on federal lands. Nat. Resour. J. 2008, 48, 585-647. 